\title{
ANTIOXIDANT AND GASTRIC ULCER HEALING EFFECT OF ORTHOSIPHON STAMINEUS (BENTH.) LEAVES EXTRACT IN ASPIRIN-INDUCED RATS
}

\author{
ARI YUNIART0 ${ }^{1 *}$, ELIS SUSILAWATI ${ }^{1}$, ISMI KHAIRUNNISA ${ }^{1}$, DADANG JUANDA ${ }^{2}$, FINNA SETIAWAN ${ }^{3}$ \\ ${ }^{1}$ Pharmacology Research Group, Bandung School of Pharmacy, Jl. Soekarno-Hatta No.754, Bandung, Indonesia. ${ }^{2}$ Pharmaceutical Biology \\ Research Group, Bandung School of Pharmacy, Jl. Soekarno-Hatta No.754, Bandung, Indonesia. ${ }^{3}$ Department of Pharmacology, University of \\ Surabaya, Jl. Ngagel Jaya Selatan, Surabaya, Indonesia. Email: ariyuniarto@yahoo.co.id
}

Received: 25 October 2016, Revised and Accepted: 02 November 2016

ABSTRACT

Objective: In the gastrointestinal system, gastric ulcer is one of the common serious problems in human life and gives contribution against morbidity and mortality incidence. The pathophysiology of gastric ulcer is an imbalance between aggressive factor and mucosal integrity factor. Increase of aggressive factors and decrease of mucosal integrity factors have potential against developed of gastric ulcer disease. The objective of the research was to evaluate antioxidant and gastric ulcer healing effect of Orthosiphon stamineus (Benth.) leaves extract in aspirin-induced rats.

Methods: In vivo antiulcer activity of Orthosiphon leaves extract was evaluated through several parameters involves gastric acidity, number of ulcers, diameters of ulcers, ulcer index (UI), and healing ratio. Dose level of Orthosiphon leaves extract which used in this study such as 250 and $500 \mathrm{mg} / \mathrm{kg}$, respectively. Antioxidant activity of Orthosiphon leaves extract was evaluated by 1,1-diphenyl-2-picrylhydrazyl hydrate (DPPH) method. Histopathological of the stomach was performed using hematoxylin-eosin stained.

Results: The results of the study showed that groups which given Orthosiphon leaves extract have significantly different for gastric ulcer healing compared to the control group and were supported by histopathological analysis. The Orthosiphon leaves extract also showed maximum scavenging activity at a concentration of $100 \mu \mathrm{g} / \mathrm{ml}\left(58.86 \%\right.$ inhibition) and minimum at $50 \mu \mathrm{g} / \mathrm{ml}\left(29.60 \%\right.$ inhibition) with inhibitory concentration $50 \%$ (IC ${ }_{50}$ ) $84.54 \mu \mathrm{g} / \mathrm{ml}$ when compared to ascorbic acid as the standard with $\mathrm{IC}_{50} 5.08 \mu \mathrm{g} / \mathrm{ml}$ by DPPH method.

Conclusion: It can be concluded that from the experimental study of $O$. stamineus (Benth.) leaves extract has potential antiulcer activity in aspirininduced rats model and antioxidant effect using DPPH method. Stomach tissues regeneration in gastric ulcer model might be affected by the improvement of antioxidant status.

Keywords: Orthosiphon stamineus (Benth.), Extract, Ulcer, Aspirin, 1,1-diphenyl-2-picrylhydrazyl hydrate.

(C) 2017 The Authors. Published by Innovare Academic Sciences Pvt Ltd. This is an open access article under the CC BY license (http://creativecommons. org/licenses/by/4. 0/) DOI: http://dx.doi.org/10.22159/ajpcr.2017.v10i2.15873

\section{INTRODUCTION}

Gastric ulcer disease affects more than 5-10\% people in their life [1]. Non-steroid anti-inflammatory drugs (NSAIDs), Helicobacter pylori infection, and stress factor are common causes of gastric ulcer disease and play a role in the pathophysiology of gastric and duodenal ulcer. Gastric ulcer is believed to be due to an imbalance between aggressive and mucosal integrity factors. Increase of aggressive factors (gastric acid and pepsin secretion) and decrease of mucosal integrity factors (inhibition of prostaglandin, decrease of bicarbonate concentration, and diminished of blood flow in gastric) have potential against developed of gastric ulcer [2-4].

Gastrointestinal toxicity associated with the use of aspirin (acetylsalicylic acid) and other non-selective NSAID against upper gastrointestinal is well documented. The long-term effect of aspirin and non-selective NSAID group administration can influence gastric mucosal integrity. These agents have been implicated in the pathophysiology of gastric and duodenal ulcer. Aspirin has two mechanisms to influence gastric damaged. First mechanism by direct irritation in gastric mucosal and second mechanism by inhibition of cyclooxygenase enzyme [5].

The goals of treating gastric ulcer disease are to reduce pain, ulcer healing, and prevent ulcer recurrence. Long-term administration of antiulcer drugs showed that these drugs give contribution against several side effects $[6,7]$. In this case, target of the current study is to find a suitable treatment for gastric ulcer from natural product sources. Several researches using natural product sources to treat gastric ulcer in experimental animal has been shown best results. The mechanism of action of natural product on tissue regeneration in gastric ulcer condition is not clear although several hypotheses have been proposed.

Orthosiphon stamineus (Benth.) can be found in Southeast Asia region involves Indonesia, Vietnam, Thailand, Malaysia, and Australia. O. stamineus (Benth.) (Family Lamiaceae), locally known as "Kumis Kucing" in Indonesia, has been used in traditional medicine for the treatment of several conditions such as arthritis disorders, diabetes mellitus, hypertension, renal disorders, and antipyretic [8,9]. Several researches explained that 0 . stamineus (Benth.) leaves also have antioxidant activity. This effect would be expected could improve tissues damaged in gastric ulcer condition.

Therefore, the aim of the present study is to evaluate gastric ulcer healing effect of 0 . stamineus (Benth.) leaves extract in aspirininduced rats model and its antioxidant activity using 1,1-diphenyl-2picrylhydrazyl hydrate (DPPH) method.

\section{METHODS}

Experimental material

All reagents in this study were of analytical grade. Aspirin ${ }^{\circledR}$ and sucralfate were purchased from Kimia Farma Pharmacy, Bandung, Indonesia. 
Plant material and identification

O. stamineus (Benth.) leaves were collected from the Centre of Research and Development of Medicinal Plants and Traditional Medicine, Central Java, Indonesia. Orthosiphon leaves identification was performed at Herbarium of Jatinangor, Laboratory of Plant Taxonomy, Department of Biology, Padjadjaran University, Indonesia.

\section{Preparation of extract}

O. stamineus (Benth.) leaves which obtained from the Centre of Research and Development of Medicinal Plants and Traditional Medicine were processed through several stages. O. stamineus (Benth.) leaves were dried and then were powdered. The powder of Orthosiphon leaves was extracted by maceration method and evaporated by Rotary Evaporator. Orthosiphon leaves extract was used for further studies.

\section{Phytochemical screening of extract}

Phytochemical screening of Orthosiphon leaves extract was performed to evaluate the presence of phytoconstituents such as alkaloids, flavonoids, saponins, tannins, quinones, and steroids/triterpenoids.

\section{Experimental animal}

Healthy adult male Wistar rats (200-250 g) were used for the experiment. Rats were maintained at controlled room with free access to food and water. 12 hrs before the experiment, rats were transferred to the Laboratory of Pharmacology Bandung School of Pharmacy and were fasted, given only water ad libitum. The experiment study was performed after approval by the Health Research Ethics Committee, Faculty of Medicine, Padjadjaran University (No.316./UN6.C1.3.2/KEPK/PN/2016).

\section{Aspirin-induced rats model}

Experimental animals were divided into five groups, each group consisting of five rats. Group I or normal group received $0.5 \%$ carboxymethyl cellulose-Na and Group II or control group received aspirin (500 mg/kg). Group III received the standard drug and Group IV and V received Orthosiphon leaves extract at the doses 250 and $500 \mathrm{mg} / \mathrm{kg}$, respectively (Group II to Group V received aspirin $500 \mathrm{mg} / \mathrm{kg}$ ). Gastric ulcer model on experimental rats was induced by administering aspirin $500 \mathrm{mg} / \mathrm{kg}$ for 2 days. After induction period, rats were sacrificed, the rats' stomach was incised along the greater curvature. Sucralfate $90 \mathrm{mg} /$ $\mathrm{kg}$ was used as the standard drug for this experiment.

The gastric juice was collected, centrifuged at $2000 \mathrm{rpm} / \mathrm{min}$ for 10 minutes. Measurement of acidity was through titration method. Furthermore, the severity of ulcers was observed and scored to determine UI. Severity score based on Gupta et al. [10] ( $0=$ Normal, $0.5=$ Redness, 1=Spot ulcer, 2=Hemorrhagic ulcer, 3=Deep ulcer, and 4=Perforation). UI was determined by the following formula of Vogel [11]

$\mathrm{UI}=\mathrm{UN}+\mathrm{US}+\mathrm{UP} \times 10^{-1}$

$\mathrm{UN}=$ Average of number of ulcers per animal

US=Average of severity score,

$\mathrm{UP}=$ Percentage of animals with ulcers.

The percentage of ulcer healing was determined as ulcer healing $(\%)=$

(UI control-UI test group)/UI control group $\times 100 \%$.

\section{Histopathological examination}

At the final of study, rats were sacrificed. The stomach was collected and washed with normal saline solution. Stomach was kept in $10 \%$ formalin solution for 24 hrs and dehydrated using alcohol, was embedded in paraffin wax, and cleaned with xylene and alcohol. Furthermore, the washed tissues were treated using hematoxylin-eosin dye. The purpose of the examination is to observe pathology condition in gastric tissues.

\section{Antioxidant assay of Orthosiphon leaves extract}

The antioxidant activity of the Orthosiphon extract was determined using DPPH method. Radical scavenging activity of $O$. stamineus (Benth.) leaves extract against DPPH was determined by spectrophotometry at $515 \mathrm{~nm}$. Ascorbic acid was used as the standard. The absorbance was carried out in triplicates. Percentage inhibition was calculated by the formula:

$A_{0}-A_{1} / A_{0} \times 100 \%$

Where, $A_{0}$ was the absorbance of control, and $A_{1}$ was the absorbance of test or standard sample.

\section{Statistical analysis}

Statistical analysis of the results of antiulcer effect was performed using one-way analysis of variance method, coupled with the post hoc Dunnett's test. A value of $\mathrm{p}<0.05$ was used to denote statistical significance. All data were expressed as mean \pm standard deviation for each group.

\section{RESULTS AND DISCUSSION}

\section{Phytochemical screening of extract}

The phytochemical screening of Orthosiphon leaves extract showed the presence of alkaloids, flavonoids, saponin, tannin, quinone, and steroids/triterpenoids compounds. These compounds might be responsible against antiulcer activity in aspirin-induced rats model.

\section{Aspirin-induced rats model}

As shown in Table 1, the standard drug (Sucralfate $90 \mathrm{mg} / \mathrm{kg}$ ), Orthosiphon leaves extract $250 \mathrm{mg} / \mathrm{kg}$, and Orthosiphon leaves extract $500 \mathrm{mg} / \mathrm{kg}$ given ulcer healing significantly different compared to the control group in a number of ulcers. Orthosiphon leaves extract with dose 250 and dose $500 \mathrm{mg} / \mathrm{kg}$ efficiently affecting diameters of ulcers and UI such as $2.94 \pm 0.08$ (15.11) and 2.67 \pm 0.47 (14.17), respectively. The UI, diameters of ulcers, and number of ulcers were found to be significantly increased in the control group. It can be concluded that both Orthosiphon leaves extract 250 and $500 \mathrm{mg} / \mathrm{kg}$ have the ability to improve stomach tissue damaged. This result is consistent with histopathological examination, where stomach tissue and inflammation area were reduced in groups given treatments with Orthosiphon leaves extract 250 and $500 \mathrm{mg} / \mathrm{kg}$ compared to the control group.

\section{Histopathological examination}

It has been observed from histopathological results showed that both Orthosiphon leaves extract 250 and $500 \mathrm{mg} / \mathrm{kg}$ have the ability to improve stomach tissues damaged. Orthosiphon leaves extract at the dose $500 \mathrm{mg} / \mathrm{kg}$ could reduce necrosis and inflammation very well compared with the dose $250 \mathrm{mg} / \mathrm{kg}$ for 7 days treatment. Sucralfatetreated rats did not show severe damage in stomach. Furthermore, control group which administered by aspirin $500 \mathrm{mg} / \mathrm{kg}$ showed the presence of inflammatory condition and deep perforation for 2 days induction (Fig. 1)

Table 1: Effect of Orthosiphon leaves extract on ulcer healing

\begin{tabular}{|c|c|c|c|c|c|}
\hline Group & Gastric pH & Number of ulcers & Diameters of ulcers (mm) & UI groups & Ulcer healing (\%) \\
\hline Normal group & $2.37 \pm 0.26$ & 0 & 0 & 0 & - \\
\hline Control group & $1.83 \pm 0.44$ & $8.3 \pm 3.29$ & $3.75 \pm 074$ & 22.05 & 0 \\
\hline Sucralfate $90 \mathrm{mg} / \mathrm{kg}$ & $2.63 \pm 0.26$ & $1.33 \pm 1.18^{*}$ & $2.33 \pm 0.47$ & $13.66^{*}$ & 38.05 \\
\hline Orthosiphon leaves extract $250 \mathrm{mg} / \mathrm{kg}$ & $2.53 \pm 0.18$ & $2.17 \pm 1.43^{*}$ & $2.94 \pm 0.08$ & $15.11^{*}$ & 31.47 \\
\hline Orthosiphon leaves extract $500 \mathrm{mg} / \mathrm{kg}$ & $2.27 \pm 0.23$ & $1.5 \pm 1.08^{*}$ & $2.67 \pm 0.47$ & $14.17^{*}$ & 35.74 \\
\hline
\end{tabular}

*Significantly different compared to control group $(\mathrm{p}<0.05)$. UI: Ulcer index 


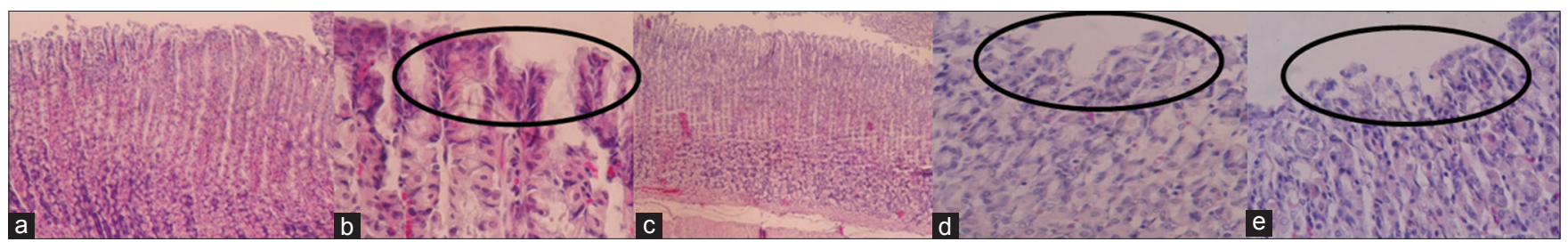

Fig. 1: (a) Normal group, (b) control group, (c) sucralfate $90 \mathrm{mg} / \mathrm{kg}$ (d) Orthosiphon leaves extract $250 \mathrm{mg} / \mathrm{kg}$, (e) Orthosiphon leaves extract $500 \mathrm{mg} / \mathrm{kg}$

\section{Antioxidant activity of Orthosiphon leaves extract}

The free radical scavenging activity of Orthosiphon leaves extract was studied by its ability to reduce the DPPH, a stable free radical. Orthosiphon leaves extract showed maximum scavenging activity at a concentration of $100 \mu \mathrm{g} / \mathrm{ml}$ (58.86\% inhibition) and minimum at $50 \mu \mathrm{g} / \mathrm{ml}(29.60 \%$ inhibition) with inhibitory concentration 50\% (IC $\left.{ }_{50}\right) 84.54 \mu \mathrm{g} / \mathrm{ml}$ when compared to ascorbic acid as the standard with IC $50.089 \mu \mathrm{g} / \mathrm{ml}$. Based on the result, Orthosiphon leaves extract has best antioxidant activity with $\mathrm{IC}_{50} 84.54 \mu \mathrm{g} / \mathrm{ml}$. The purpose of antioxidant activity assay in the present study is to find a correlation between antioxidant status and stomach tissues regeneration. Necrosis, inflammation, and diminished of mucosal integrity factors have the ability to activating several inflammatory mediators and macrophage which contributed to oxidative stress [12].

The ability of Orthosiphon leaves extract in gastric ulcer healing is depends on its antioxidant activity. The antioxidant activity of Orthosiphon leaves extract is suggested because the presence of flavonoids compound. This mechanism might be through decrease of free radical formation. Other compounds involve alkaloids, saponin, tannin, quinone, and steroids/ triterpenoids in Orthosiphon leaves extract also supporting stomach tissues regeneration through unknown mechanism.

\section{CONCLUSION}

Based on the experimental study showed that 0 . stamineus (Benth.) leaves extract has potentially antiulcer activity in aspirin-induced rats and best antioxidant activity using DPPH method. Stomach tissue regeneration in gastric ulcer model might be affected by improvement of antioxidant status.

\section{ACKNOWLEDGMENT}

This research was supported by Internal Research Grant from the Centre of Research and Community Services (P3M), Bandung School of Pharmacy, West Java, Indonesia.

\section{REFERENCES}

1. Ewadh M, Al-Bayati N, Ijam A. Role of leukotriene in gastric ulcer induced by acetylsalicylic acid in male rabbits: Gastroprotection by montelucast. Adv Life Sci Technol 2015;28:7-14.

2. García Rodríguez LA, Hernández-Díaz S. Risk of uncomplicated peptic ulcer among users of aspirin and nonaspirin nonsteroidal antiinflammatory drugs. Am J Epidemiol 2004;159(1):23-31.

3. Sostres C, Carrera-Lasfuentes P, Benito R, Roncales P, Arruebo M, Arroyo MT, et al. Peptic ulcer bleeding risk. The role of Helicobacter pylori infection in NSAID/low-dose aspirin users. Am J Gastroenterol 2015;110(5):684-9.

4. Quan C, Talley NJ. Management of peptic ulcer disease not related to Helicobacter pylori or NSAIDs. Am J Gastroenterol 2002;97(12):2950-61.

5. Matsui H, Shimokawa O, Kaneko T, Nagano Y, Rai K, Hyodo I. The pathophysiology of non-steroidal anti-inflammatory drug (NSAID)induced mucosal injuries in stomach and small intestine. J Clin Biochem Nutr 2011;48(2):107-11.

6. McCarthy DM. Adverse effects of proton pump inhibitor drugs: Clues and conclusions. Curr Opin Gastroenterol 2010;26(6):624-31.

7. Singh KD, Chetia D, Junejo JA. Antiulcer and in vitro antioxidant activity of Allium hookeri: An ethnomedicinal plant of Manipur. Asian J Pharm Clin Res 2015;8(5):130-5.

8. Adnyana IK, Setiawan F, Insanu M. From ethnopharmacology to clinical study of Orthosiphon stamineus (Benth). Int J Pharm Pharm Sci 2013;5(3):66-73.

9. Alshawsh MA, Abdulla MA, Ismail S, Amin ZA, Qader SW, Hadi HA, et al. Free radical scavenging, antimicrobial and immunomodulatory activities of Orthosiphon stamineus. Molecules 2012;17(5):5385-95.

10. Gupta J, Dinesh K, Ankit G. Evaluation of gastric anti-ulcer activity of methanolic extract of Cayratia trifolia in experimental animals. Asian Pac J Trop Dis 2012;2(2):99-102.

11. Vogel HG. Drug Discovery and Evaluation: Pharmacological Assays. Berlin: Springer-Verlag; 1997. p. 1235-40.

12. Bhattacharyya A, Chattopadhyay R, Mitra S, Crowe SE. Oxidative stress: An essential factor in the pathogenesis of gastrointestinal mucosal diseases. Physiol Rev 2014;94(2):329-54. 